Article

\title{
Mycobiota and Mycotoxins in Traditional Medicinal Seeds from China
}

\author{
Amanda Juan Chen ${ }^{\dagger}$, Xiaolin Jiao ${ }^{\dagger}$, Yongjian Hu, Xiaohong Lu and Weiwei Gao * \\ Institute of Medicinal Plant Development, Chinese Academy of Medical Sciences and Peking Union \\ Medical College, Beijing 100193, China; E-Mails: amanda_j_chen@163.com (A.J.C.); \\ jiao_1110@163.com (X.J.); hu713th@163.com (Y.H.); luchauluchau@gmail.com (X.L.) \\ $\dagger$ These authors contributed equally to this work. \\ * Author to whom correspondence should be addressed; E-Mail: wwgao411@sina.com; \\ Tel.: +86-10-5783-3423; Fax: +86-10-5783-3020.
}

Academic Editor: Laura Anfossi

Received: 4 August 2015 / Accepted: 15 September 2015 / Published: 24 September 2015

\begin{abstract}
The multi-mycotoxin occurrence for internal and superficial fungi contamination were comprehensively assessed in medicinal seeds used as food or beverage. Based on a polyphasic approach using morphological characters, $\beta$-tubulin and ITS gene blast, a total of 27 species belonging to 12 genera were identified from surface-sterilized seeds. Chaetomium globosporum was most predominant (23\%), followed by Microascus trigonosporus (12\%) and Alternaria alternata (9\%). With respect to superficial mycobiota, thirty-four species belonging to 17 genera were detected. Aspergillus niger and Penicillium polonicum were predominant (12\% and $15 \%$, respectively). Medicinal seed samples and potential toxigenic fungi were tested for ochratoxin A (OTA) and aflatoxins (AFB1, AFB2, AFG1, AFG2) using UPLC-MS/MS. Platycladi seeds were contaminated with AFB1 $(52.0 \mu \mathrm{g} / \mathrm{kg})$ and tangerine seed was contaminated with OTA $(92.3 \mu \mathrm{g} / \mathrm{kg})$. Subsequent analysis indicated that one A. flavus strain isolated from platycladi seed was able to synthesize AFB1 $(102.0 \mu \mathrm{g} / \mathrm{kg})$ and AFB2 $(15.3 \mu \mathrm{g} / \mathrm{kg})$. Two $P$. polonicum strains isolated from tangerine and lychee seeds were able to synthesize OTA $(4.1 \mu \mathrm{g} / \mathrm{kg}$ and $14.8 \mu \mathrm{g} / \mathrm{kg}$, respectively). These results identify potential sources of OTA and aflatoxins in medicinal seeds and allude to the need to establish permitted limits for these mycotoxins in these seeds that are commonly consumed by humans.
\end{abstract}


Keywords: medicinal seeds; mycobiota; UPLC-MS/MS; aflatoxins; ochratoxin A; mycotoxigenic fungi

\section{Introduction}

According to the World Health Organization, $80 \%$ of people living in developing countries rely on traditional herbal medicines [1]. Herbal and other alternative treatments are also popular in the developed world, where they are used by about half of Australians and one third of Americans [2,3]. China is one of the largest producers of traditional herbal medicines (THM) in the world. According to 2011 Chinese customs statistics, 2.3 billion dollars of THM were exported to Japan, the United States and European Union, among other countries [4]. In THM, parts of botanicals such as roots, leaves, flowers, seeds, etc., are separately used to acquire the best pharmaceutical effect. So far, more than 60 medicinal seeds have been recorded in the pharmacopoeia of China [5]. Many of these are not only used medically; some medicinal seeds such as coix seed, lotus seed and cassia seed are also considered dietary herbs, which are widely used in foods and health drinks [6,7].

Medicinal seeds are commonly infected in the field (pre-harvest) or during storage (post-harvest) with various molds which may result in the production of mycotoxins. Currently, more than 400 mycotoxins have been identified, but the most significant classes of mycotoxins [8], with respect to their toxic or carcinogenic properties, include aflatoxins (AFs) [9] and ochratoxin A (OTA) [10]. AFs are hepatotoxic, teratogenic, mutagenic and carcinogenic mycotoxins produced by members of Aspergillus section Flavi, in particular A. flavus and A. parasiticus [11]. The most potent of the four naturally occurring AFs (B1, B2, G1 and G2) is aflatoxin B1 (AFB1), which is listed as a group I carcinogen by the International Agency for Research on Cancer [9] because of its demonstrated carcinogenicity to humans.

Apart from AFs, OTA is one of the most important mycotoxins and the most toxic member of the ochratoxin group. OTA exhibits teratogenic, embryotoxic, genotoxic, neurotoxic, immunosuppressive, carcinogenic [12], and nephrotoxic effects [13,14]. The most important ochratoxigenic Aspergillus spp. are members of Aspergillus section Nigri and section Circumdati [15-17]. Penicillium nordicum and $P$. verrucosum are the primary OTA producers in the Penicillium genera $[18,19]$. In addition, Penicillium spp. including $P$. chrysogenum, $P$. glycyrrhizacola and $P$. polonicum have been described as a primary source of OTA contamination in liquorice roots [20,21].

Due to AFs' toxicological effects, the maximum permitted levels in several medicinal herbs have been set in China, to $5 \mu \mathrm{g} / \mathrm{kg}$ for AFB1 and $10 \mu \mathrm{g} / \mathrm{kg}$ for the sum of AFB1, AFB2, AFG1 and AFG2 [5]. With respect to OTA, the maximum permitted level was set in liquorice root to $20 \mu \mathrm{g} / \mathrm{kg}$ by the European Commission (EC) Regulation No 105/2010 [22] and amending Regulation 1881/2006 [23]. The problems of AFB1 contamination have been well documented in several medicinal seeds including platycladi seed and coix seed [24-26]. However, little research has been conducted to describe the occurrence of OTA and mycotoxigenic fungi. The purpose of the present study is: (1) to determine the simultaneous occurrence of aflatoxins (AFB1, B2, G1, G2) and OTA in twelve commonly used medicinal seeds; and (2) to determine the mycobiota associated with these medicinal seeds and their potential ability to produce mycotoxins. 


\section{Results and Discussion}

\subsection{Water Activity}

The water activity $\left(\mathrm{a}_{\mathrm{w}}\right)$ of the studied medicinal seeds ranged from $0.65 \pm 0.00$ to $0.84 \pm 0.06$ (Figure 1). The highest water activity was found in tangerine seeds $\left(0.84 \pm 0.06 \mathrm{a}_{\mathrm{w}}\right)$, followed by lychee seeds $\left(0.79 \pm 0.02 \mathrm{a}_{\mathrm{w}}\right)$, platycladi seeds $\left(0.79 \pm 0.02 \mathrm{a}_{\mathrm{w}}\right)$, and Chinese dodder seeds $\left(0.74 \pm 0.00 \mathrm{a}_{\mathrm{w}}\right)$.

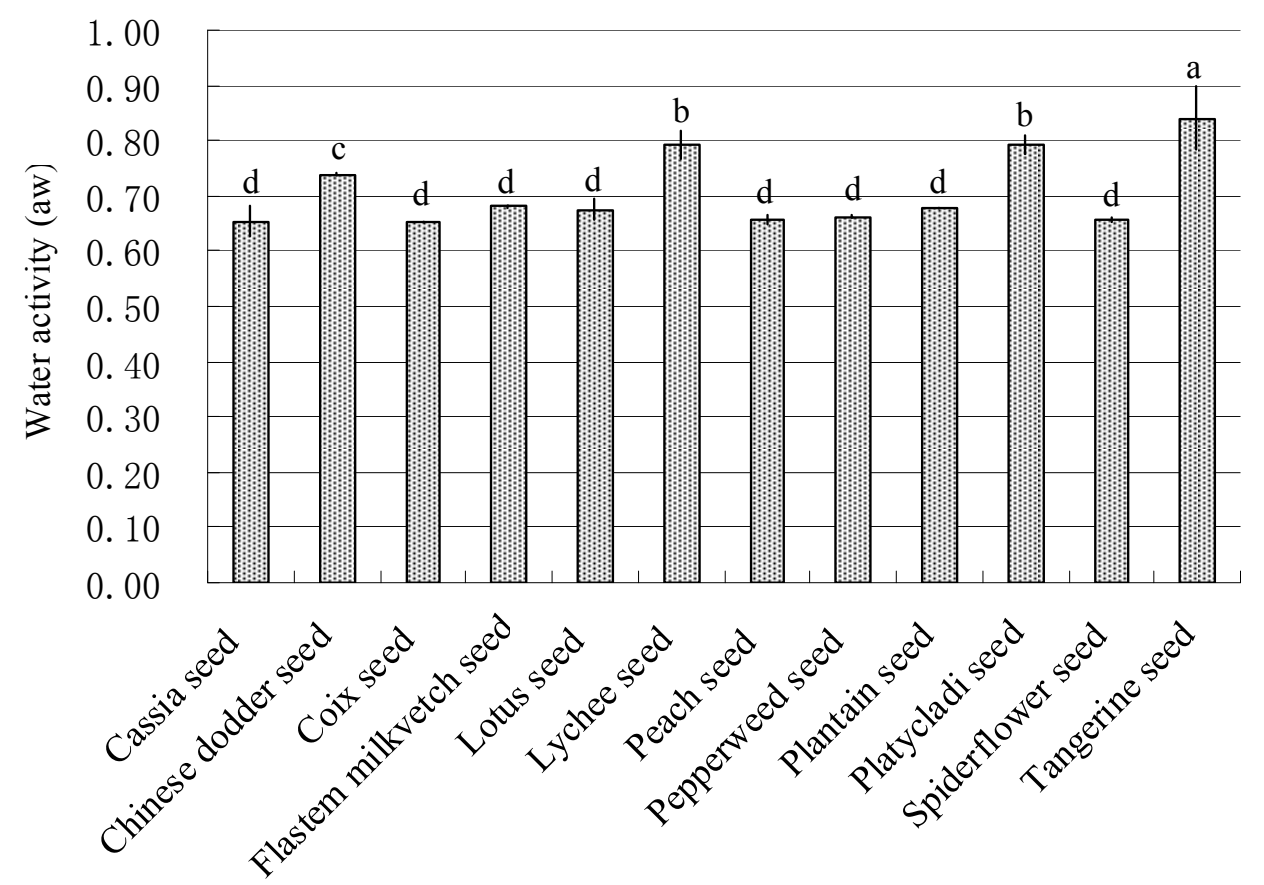

Figure 1. Water activity of tested medicinal seeds. The data are means $\pm \operatorname{SD}(n=3)$, and data were analyzed using an LSD test. The same letters above each of the bars indicate no significant difference in mean values of water activity of seed samples $(p \geq 0.05)$, while different letters indicate significant difference $(p<0.05)$.

\subsection{Internal Fungal Incidence}

Different infection frequencies that ranged from $2 \%$ to $100 \%$ were observed, except that no internal fungi were acquired from pepperweed and flastem milkvetch seed samples (Table 1). A total of 352 fungal isolates belonging to 12 genera and 27 species were detected from infected seeds. Chaetomium globosporum was the most commonly identified fungi, which could be detected in 4 out of 10 medicinal seed samples. Isolates related to C. globosporum represented $23 \%$ of the total internal fungal counts, whereas isolates related to Microascus trigonosporus and Alternaria alternata accounted for $12 \%$ and $9 \%$ of total internal fungal counts, respectively. 
Table 1. Internal fungal incidence (CFU/100 seed) in studied medicinal seeds ${ }^{\text {a }}$.

\begin{tabular}{|c|c|c|c|c|c|c|c|c|c|c|c|c|}
\hline Fungal Species & $\begin{array}{c}\text { Tangerine } \\
\text { Seed } \\
\end{array}$ & $\begin{array}{c}\text { Lychee } \\
\text { Seed }\end{array}$ & $\begin{array}{c}\text { Platycladi } \\
\text { Seed } \\
\end{array}$ & $\begin{array}{c}\text { Spiderflower } \\
\text { Seed }\end{array}$ & $\begin{array}{c}\text { Peach } \\
\text { Seed }\end{array}$ & $\begin{array}{l}\text { Coix } \\
\text { Seed } \\
\end{array}$ & $\begin{array}{c}\text { Plantain } \\
\text { Seed }\end{array}$ & $\begin{array}{c}\text { Lotus } \\
\text { Seed } \\
\end{array}$ & $\begin{array}{c}\text { Cassia } \\
\text { Seed } \\
\end{array}$ & $\begin{array}{c}\text { Chinese } \\
\text { Dodder Seed }\end{array}$ & Sum & $\begin{array}{c}\text { Frequency } \\
\% \\
\end{array}$ \\
\hline Acremonium sp. & & 9 & & & & & & & & & 9 & 2.56 \\
\hline Alternaria alternata & & & & 28 & & & & & 2 & & 30 & 8.52 \\
\hline Aspergillus flavus & & & 25 & & & & & & & 1 & 26 & 7.39 \\
\hline Aspergillus fumigatus & & 15 & 14 & & & & & & & & 29 & 8.24 \\
\hline Aspergillus nidulans & & 20 & & & & & & & & & 20 & 5.68 \\
\hline Aspergillus niger & & & 27 & & & & & & & & 27 & 7.67 \\
\hline Aspergillus proliferans & & 2 & & & & & & & & & 2 & 0.57 \\
\hline Aspergillus steynii & 2 & & & & & & & & & & 2 & 0.57 \\
\hline Aspergillus tubingensis & 2 & & & & & & & & & & 2 & 0.57 \\
\hline Aspergillus versicolor & 2 & & & & & & & & & & 2 & 0.57 \\
\hline Botryophaeria sp. & & & 1 & & & & & & & & 1 & 0.28 \\
\hline Chaetomium globosporum & 39 & 16 & & & 22 & & 4 & & & & 81 & 23.01 \\
\hline Cochliobolus sativus & & & & & & 2 & & & & & 2 & 0.57 \\
\hline Eurotium amstelodami & & 19 & & & & & & & & & 19 & 5.4 \\
\hline Eurotium chevalieri & & 3 & & & & & & & & & 3 & 0.85 \\
\hline Eurotium repens & 5 & & 1 & & & & & & & & 6 & 1.7 \\
\hline Eurotium rubrum & & 16 & & & & & & & & & 16 & 4.55 \\
\hline Fusarium incarnatum & & & & & & 2 & & & & & 2 & 0.57 \\
\hline Microascus cirrosus & 5 & & & & & & & & & & 5 & 1.42 \\
\hline Paecilomyces variotii & & 2 & & & & & & & & & 2 & 0.57 \\
\hline Penicillium aurantiogriseum & & & & & & & & 2 & & & 2 & 0.57 \\
\hline Penicillium bilaiae & 6 & & & & & & & & & & 6 & 1.7 \\
\hline Penicillium polonicum & 7 & & & 2 & & & & & & 1 & 10 & 2.84 \\
\hline Penicillium solitum & 3 & & & & & & & & & & 3 & 0.85 \\
\hline
\end{tabular}


Table 1. Cont.

\begin{tabular}{|c|c|c|c|c|c|c|c|c|c|c|c|c|}
\hline Fungal Species & Tangerine Seed & Lychee Seed & $\begin{array}{c}\text { Platycladi } \\
\text { Seed } \\
\end{array}$ & $\begin{array}{c}\text { Spiderflower } \\
\text { Seed } \\
\end{array}$ & $\begin{array}{c}\text { Peach } \\
\text { Seed }\end{array}$ & $\begin{array}{l}\text { Coix } \\
\text { Seed }\end{array}$ & $\begin{array}{c}\text { Plantain } \\
\text { Seed } \\
\end{array}$ & $\begin{array}{c}\text { Lotus } \\
\text { Seed }\end{array}$ & $\begin{array}{c}\text { Cassia } \\
\text { Seed }\end{array}$ & $\begin{array}{c}\text { Chinese } \\
\text { Dodder Seed }\end{array}$ & Sum & $\begin{array}{c}\text { Frequency } \\
\% \\
\end{array}$ \\
\hline $\begin{array}{l}\text { Penicillium } \\
\text { spinulosum }\end{array}$ & 2 & & & & & & & & & & 2 & 0.57 \\
\hline Phoma sp. & & & & & & 2 & & & & & 2 & 0.57 \\
\hline $\begin{array}{l}\text { Microascus } \\
\text { trigonosporus }\end{array}$ & 41 & & & & & & & & & & 41 & 11.65 \\
\hline $\begin{array}{l}\text { Infected seeds No. } \\
\qquad / 100 \text { seeds }\end{array}$ & 100 & 92 & 59 & 30 & 22 & 6 & 4 & 2 & 2 & 2 & & \\
\hline $\begin{array}{l}\text { Seeds infected with } \\
\text { more than two } \\
\text { fungal species }\end{array}$ & 20 & 9 & 10 & 0 & 0 & 0 & 0 & 0 & 0 & 0 & & \\
\hline $\begin{array}{l}\text { Co-infected fungal } \\
\text { species }\end{array}$ & $\begin{array}{c}\text { Chaetomiun } \\
\text { globosporum + } \\
\text { Penicillium spp. }\end{array}$ & $\begin{array}{c}\text { Eurotium spp. }+ \\
\text { Aspergillus spp./ } \\
\text { Eurotium spp. }+ \\
\text { Chaetomium } \\
\text { globosporum }\end{array}$ & $\begin{array}{l}\text { Aspergillus } \\
\text { niger }+ \\
\text { Aspergillus } \\
\text { flavus }\end{array}$ & & & & & & & & & \\
\hline
\end{tabular}

${ }^{a}$ none internal fungi were acquired from pepperweed seed and flastem milkvetch seed samples. 
Tangerine, lychee, and platycladi seeds exhibited the highest fungal infection rates, which may be related to their elevated water activity. Among them, 100\% of tangerine seeds was found to be infected by fungi and $20 \%$ were co-infected with C. globosporum and Penicillium spp. (P. bilaiae, P. polonicum). Ninety-two percent of lychee seeds were found to be infected by fungi and $9 \%$ were co-infected with Eurotium spp. (E. amstelodami, E. chevalieri, E. rubrum) and Aspergillus spp. (A. fumigatus, A. nidulans) or with Eurotium spp. (E. amstelodami, E. chevalieri, E. rubrum) and C. globosporum. Fifty-nine percent of platycladi seeds were found to be infected with fungi and $10 \%$ were co-infected with $A$. niger and A. flavus.

Plant seeds are rich in starch, protein, and fat and are thus highly susceptible to fungal contamination and growth during harvesting and storage. A number of survey and monitoring programs have been carried out in several countries that have attempted to define a general pattern of the contaminated mycobiota in association with edible seeds. These included maize, cocoa beans, peanut, and other cereals. Mycobiota associated with these seeds included Aspergillus spp., Penicillium spp., Fusarium spp., and Alternaria spp. [27-32]. By contrast, little research has been focused on characterizing the mycobiota that associate with medicinal seeds. Kong et al. [25] analyzed the mycobiota associated with 4 medicinal seeds including coix, lotus, bitter apricot, and ginkgo seeds. Their results indicated that coix seed was most contaminated (contamination confirmed in 5\%-9\% of total seeds) followed by lotus seed (contamination confirmed in $7 \%$ of total seeds), ginkgo seed (contamination confirmed in $6 \%$ of total seeds) and bitter apricot seed (contamination confirmed in $4 \%$ of total seeds). The contaminating mycobiota included $A$. flavus section, A. niger section and A. ochraceus section. According to our findings, $4 \%$ of coix seeds were infected with $F$. incarnatum and Cochliobolus sativus and $2 \%$ of lotus seeds were infected with $P$. aurantiogriseum. Different mycobiota were commonly observed in other edible seeds too, such as in maize, A. niger and A. flavus were predominant maize mycobiota when cultivated in hot climatic conditions, while Fusarium spp. was more prevalent when maize was cultivated in a warm climate [27,29]. Another alternative explanation is that field fungi including Fusarium, Alternaria, and Cochliobolus infect seeds at an early stage during plant growth in the field, whereas Penicillium and Aspergillus tend to infect seeds during storage, in particular when storage conditions are poor [33-36].

Compared with other medicinal seeds, tangerine and lychee seeds are coated with juicy, sugary pulp or aril, which is difficult to completely remove during the processing procedure. This substrate may increase the susceptibility of these two seeds to high fungal contamination. With respect to platycladi seeds, the high fatty oil content $(12 \%-51 \%)$ may increase the susceptibility of these seeds to fungal infection [37]. Numerous studies have documented the effect of lipids on the growth of the fungi A. flavus and A. parasiticus. Mellon et al. [38] determined that A. flavus growth was more supported on media with triglycerides as a sole carbon source than observed on raffinose reference medium. In addition, AF production levels were found to be 800 -fold higher when A. flavus was grown with lipid-rich substrates compared to growth with the same substrate without lipid.

Co-infections were found between C. globosporum and Penicillium spp., Eurotium spp. and Aspergillus spp., Eurotium spp. and C. globosporum, and A. niger and A. flavus. Co-infections with A. niger and A. flavus have been reported in several studies [29,31,39], and are likely attributable to the fact that sections Flavi and Nigri share common habitats and physiological characteristics. Thus, conditions that favor the growth of one of these fungi probably favor the growth of the other [39-41]. 
Alternatively, such results may reflect facilitative interactions between these populations, whereby growth of one strain creates conditions (e.g., nutrients) conducive to the growth of the other strain. The positive correlation observed between co-infection of C. globosporum and other fungi in medicinal seeds may be due to a similar phenomenon, since this fungus is widespread and could produce high amounts of cellulase complex [42]. The cellulase produced might benefit other fungi during infection of medicinal seeds. Recently C. globosporum was detected in cumin (Cuminum cyminum) and aniseed (Pimpinella anisum) too [43].

\subsection{Incidence of Superficial Fungi on Seed Surfaces}

Total fungal counts ranged from $6.5 \times 10^{1}$ to $8.1 \times 10^{4} \mathrm{CFU} / \mathrm{g}$ seed. Among the twelve kinds of medicinal seeds tested, flastem milkvetch, coix, lychee, lotus, and Chinese dodder seeds exhibited lower levels of fungal contamination, which ranged from $6.5 \times 10^{1}$ to $4.5 \times 10^{2} \mathrm{CFU} / \mathrm{g}$. The other seven medicinal seeds were highly contaminated, with fungal counts ranging from $6.75 \times 10^{3}$ to $8.1 \times 10^{4} \mathrm{CFU} / \mathrm{g}$, (Table 2). The superficial fungal counts have little to do with the seed size.

A total of 34 species of fungi belonging to 17 genera were detected among these CFUs (Table 2). Aspergillus, Penicillium, Mucor, and Fusarium were the four most predominant genera detected in association with all medicinal seeds (exception being spiderflower seed) which represented about $41 \%$, $29 \%, 6 \%$ and $5 \%$ of the total CFUs, respectively. The most common genus identified was Aspergillus and this was represented by 9 species, among which $A$. niger was most predominant (about $12 \%$ of total), followed by $A$. versicolor (about 7\% of total), A. tubingensis (about $7 \%$ of total), and A. fumigatus (about $5 \%$ of total). The second common genus, Penicillium, was represented by 9 species, among which P. polonicum was most predominant. P. polonicum was isolated from 10 of the 12 medicinal seed samples and represented about $15 \%$ of the total CFUs, followed by $P$. citrinum (about $5 \%$ of total) and P. aurantiogriseum (about $5 \%$ of total).

Comparison between different medicinal seeds revealed $A$. niger as the most predominant species in association with platycladi seed and Chinese dodder seed, representing $72 \%$ and $28 \%$ of the total CFUs, respectively. A. fumigatus, A. sydowii, A. tubingensis, A. versicolor, F. incarnatum, M. racemosus, Paecilomyces variotii, $P$. aurantiogriseum, $P$. citrinum and $P$. polonicum were predominant in plantain, pepperweed, lotus, cassia, spiderflower, flastem milkvetch, coix, peach, tangerine and lychee seeds, respectively.

In this study, large numbers of superficial fungi were observed and low similarity was found between superficial and internal mycobiota. Bayman et al. [39] also reported that the abundance of Aspergillus spp. and Penicillium spp. of surface-sterilized pistachio nuts were significantly lower than that of unsterilized nuts.

$F$. incarnatum and $A$. alternate were the two most predominant species associated with spiderflower seed, where they represented about $51 \%$ and $33 \%$ of the total CFUs, respectively. Surprisingly, Aspergillus spp. and Penicillium spp. were not detected. The reason for this observation may be that spiderflower seed is not a suitable substrate for Aspergillus spp. and Penicillium spp. An alternative explanation is that competitive interactions exist between Fusarium spp. and Aspergillus spp./Penicillium spp. In support of the latter hypothesis, several studies have previously reported a negative correlation between the distribution of Fusarium spp. and Penicillium spp. in corn grains $[44,45]$. 
Table 2. Superficial fungal incidence (\%) in studied medicinal seeds. The percent of CFUs associated with a given genus are given for each seed.

\begin{tabular}{|c|c|c|c|c|c|c|c|c|c|c|c|c|c|}
\hline Fungal Species & $\begin{array}{c}\text { Tangerine } \\
\text { Seed }\end{array}$ & $\begin{array}{l}\text { Lychee } \\
\text { Seed }\end{array}$ & $\begin{array}{l}\text { Platycladi } \\
\text { Seed }\end{array}$ & $\begin{array}{c}\text { Spiderflower } \\
\text { Seed }\end{array}$ & $\begin{array}{l}\text { Peach } \\
\text { Seed }\end{array}$ & $\begin{array}{l}\text { Coix } \\
\text { Seed }\end{array}$ & $\begin{array}{c}\text { Plantain } \\
\text { Seed }\end{array}$ & $\begin{array}{l}\text { Lotus } \\
\text { Seed }\end{array}$ & $\begin{array}{c}\text { Cassia } \\
\text { Seed }\end{array}$ & $\begin{array}{c}\text { Chinese } \\
\text { Dodder } \\
\text { Seed }\end{array}$ & $\begin{array}{c}\text { Flastem } \\
\text { Milkvetch } \\
\text { Seed }\end{array}$ & $\begin{array}{c}\text { Pepperweed } \\
\text { Seed }\end{array}$ & $\begin{array}{c}\text { Relative } \\
\text { Frequency } \\
\%\end{array}$ \\
\hline Absedia sp. & & & & & & & 8.00 & & & & & & 0.67 \\
\hline Acremonium sp. & & & & & & & & & & & 3.03 & & 0.25 \\
\hline Alternaria alternata & & & & 33.33 & & & & & & & & 5.88 & 3.27 \\
\hline Aspergillus candidus & & & & & & 4.11 & & & & & & & 0.34 \\
\hline Aspergillus flavus & 12.12 & & 23.03 & & 2.67 & & & & & & 3.03 & & 3.40 \\
\hline Aspergillus fumigatus & & 9.84 & & & 5.33 & 2.74 & 40.00 & & 3.70 & & & & 5.13 \\
\hline Aspergillus nidulans & & & & & 1.33 & & & & & 5.56 & & & 0.57 \\
\hline Aspergillus niger & & & 72.47 & & 22.67 & & 16.00 & & & 28.00 & 9.09 & & 12.35 \\
\hline Aspergillus ochraceus & & 31.15 & & & & & & 8.00 & & & & & 3.26 \\
\hline Aspergillus sydowii & & & & & & & & 4.00 & & & 12.12 & 23.53 & 3.30 \\
\hline Aspergillus tubingensis & & & & & & & & 56.00 & & & 12.12 & 5.88 & 6.17 \\
\hline Aspergillus versicolor & & & & & & & 4.00 & 4.00 & 66.67 & & & 5.88 & 6.71 \\
\hline Bispora sp. & & & & & & & & & & & & 5.88 & 0.49 \\
\hline $\begin{array}{l}\text { Chaetomium } \\
\text { globosporum }\end{array}$ & & & & & & & & & & 5.56 & 3.03 & 5.88 & 1.21 \\
\hline $\begin{array}{l}\text { Cladosporium } \\
\text { cladosporioides }\end{array}$ & & & & 13.89 & & & & 12.00 & & & 6.06 & & 2.66 \\
\hline Eurotium repens & & & & & & 16.44 & & & & & & & 1.37 \\
\hline Fusarium incarnatum & & & & 50.93 & & & & & & & & & 4.24 \\
\hline Fusarium solani & & & & & & & & & & & & 11.76 & 0.98 \\
\hline Mucor racemosus & & & & & 1.33 & & 12.00 & 4.00 & 3.70 & 26.00 & 27.27 & & 6.19 \\
\hline Paecilomyces variotii & & & & & & 64.38 & & & & & & & 5.37 \\
\hline $\begin{array}{c}\text { Penicillium } \\
\text { aurantiogriseum }\end{array}$ & & & & & 65.33 & & & & & & & & 5.44 \\
\hline Penicillium chrysogenum & & 3.28 & & & & & & & & & 3.03 & & 0.53 \\
\hline
\end{tabular}


Table 2. Cont.

\begin{tabular}{|c|c|c|c|c|c|c|c|c|c|c|c|c|c|}
\hline Fungal Species & $\begin{array}{c}\text { Tangerine } \\
\text { Seed }\end{array}$ & $\begin{array}{c}\text { Lychee } \\
\text { Seed }\end{array}$ & $\begin{array}{l}\text { Platycladi } \\
\text { Seed }\end{array}$ & $\begin{array}{c}\text { Spiderflower } \\
\text { Seed }\end{array}$ & $\begin{array}{l}\text { Peach } \\
\text { Seed }\end{array}$ & $\begin{array}{l}\text { Coix } \\
\text { Seed }\end{array}$ & $\begin{array}{c}\text { Plantain } \\
\text { Seed }\end{array}$ & $\begin{array}{l}\text { Lotus } \\
\text { Seed }\end{array}$ & $\begin{array}{l}\text { Cassia } \\
\text { Seed }\end{array}$ & $\begin{array}{c}\text { Chinese } \\
\text { Dodder } \\
\text { Seed }\end{array}$ & $\begin{array}{c}\text { Flastem } \\
\text { Milkvetch } \\
\text { Seed }\end{array}$ & $\begin{array}{l}\text { Pepperweed } \\
\text { Seed }\end{array}$ & $\begin{array}{c}\text { Relative } \\
\text { Frequency } \\
\%\end{array}$ \\
\hline Penicillium citrinum & 48.48 & & 4.49 & & & & & 4.00 & & & 3.03 & 5.88 & 5.49 \\
\hline Penicillium commune & & & & & & 1.37 & & & 3.70 & & & & 0.42 \\
\hline Penicillium implicatum & & & & & & & & & & 5.56 & & & 0.46 \\
\hline Penicillium oxalicum & 1.21 & & & 1.54 & & & & & & & 3.03 & & 0.48 \\
\hline Penicillium polonicum & 38.18 & 55.74 & & & 1.33 & 5.48 & 20.00 & 4.00 & 18.52 & 11.11 & 15.15 & 11.76 & 15.11 \\
\hline Penicillium variabile & & & & & & & & 4.00 & & & & & 0.33 \\
\hline Penicillium viridicatum & & & & & & & & & 3.70 & & & & 0.31 \\
\hline Phialophora sp. & & & & & & 4.11 & & & & & & & 0.34 \\
\hline Phoma sp. & & & & & & & & & & & & 5.88 & 0.49 \\
\hline Scopulariopsis sp. & & & & & & & & & & & & 11.76 & 0.98 \\
\hline Trichoderma koningii & & & & & & & & & & 11.11 & & & 0.93 \\
\hline Vlocladium sp. & & & & & & 1.37 & & & & 5.56 & & & 0.58 \\
\hline Total fungal counts & $4.13 \times$ & $1.53 \times$ & $4.25 \times$ & $8.1 \times$ & $1.88 \times$ & $1.83 \times$ & $6.25 \times$ & $6.5 \times$ & $6.75 \times$ & $4.5 \times$ & $8.25 \times$ & $5.75 \times$ & \\
\hline$(\mathrm{CFU} / \mathrm{g})$ & $10^{4}$ & $10^{2}$ & $10^{4}$ & $10^{4}$ & $10^{4}$ & $10^{2}$ & $10^{4}$ & $10^{1}$ & $10^{3}$ & $10^{2}$ & $10^{1}$ & $10^{4}$ & \\
\hline
\end{tabular}




\subsection{Occurrence of Mycotoxins (Aflatoxins and OTA) in Medicinal Seeds and Fungal Cultures}

Co-occurrence of aflatoxins and OTA were determined by an optimized UPLC-MS/MS method (Figure 2). The frequency of aflatoxins and OTA was low in analyzed medicinal seed samples. Aflatoxin B1 was only detected in platycladi seeds, and OTA was only detected in tangerine seeds. However, the contamination levels were very high, $52.0 \mu \mathrm{g} / \mathrm{kg}$ for AFB1 in platycladi seeds and $92.3 \mu \mathrm{g} / \mathrm{kg}$ for OTA in tangerine seeds. The high AFB1 levels $(5.61-27.8 \mu \mathrm{g} / \mathrm{kg})$ in platycladi seeds have been reported in several studies [24,26]. Accordingly, the maximum permitted levels of aflatoxins in this seed have been established in China ( $5 \mu \mathrm{g} / \mathrm{kg}$ for $\mathrm{AFB} 1$ and $10 \mu \mathrm{g} / \mathrm{kg}$ for the sum of AFB1, AFG1, AFB2, and AFG2) [5]. In contrast, OTA occurrence in medicinal seeds has rarely been studied, and this is the first report concerning high OTA levels in tangerine seeds. Considering the vulnerability of several traditional Chinese medicines to OTA, we suggest that a maximum permitted level for this mycotoxin is urgently needed.

Forty strains of 6 potentially toxigenic species including A. flavus, A. niger, A. ochraceus, A. tubingensis, P. chrysogenum and P. polonicum were screened for aflatoxin and OTA production. AFB1 and AFB2 were detected in one A. flavus strain (strain number: Platycladi-3-3) isolated from platycladi seeds at levels of $102.0 \mu \mathrm{g} / \mathrm{kg}$ and $15.3 \mu \mathrm{g} / \mathrm{kg}$, respectively, suggesting this fungus as the source of AFB1 contamination in platycladi seeds. The sequence of the beta-tubulin gene from this strain was deposited in GenBank with accession number KT737451 (Table S1). The other four A. flavus strains isolated from flastem milkvetch, tangerine, peach and Chinese dodder seeds were not found to produce AFs. Several studied reported that the highly variable aflatoxigenic profile of $A$. flavus populations seems to depend as much on the geographic region where the organism was isolated as on the growth substrate. For example, $A$. flavus isolates from peanuts seem to be predominantly aflatoxigenic $(70 \%-100 \%$ of all isolates) which is substantially higher than in other crops, independent of the geographic region where the crops were grown $[35,46,47]$. In this study, platycladi seeds seem to be a more suitable substrate for aflatoxigenic strains when compared to other medicinal seeds. OTA could be detected in one $P$. polonicum strain isolated from tangerine seeds (strain number: Tangerine-3-3) and one $P$. polonicum strain isolated from lychee seeds (strain number: Lychee-2-2) at levels of $4.1 \mu \mathrm{g} / \mathrm{kg}$ and $14.8 \mu \mathrm{g} / \mathrm{kg}$, respectively. The sequences of the beta-tubulin gene from the two strains were deposited in GenBank with accession numbers KT737453 (Table S2) and KT737452 (Table S3). This fungal genus has been implicated as a primary OTA contributor in liquorice root [20,21]. It seems that this fungus is also an important OTA contributor in medicinal seeds because of its wide distribution and toxigenic features. However, since we only detect several $P$. polonicum isolates in this experiment, the ability of this species to produce OTA still needs to be confirmed in further studies. AFs and OTA were not detected in the other 4 species. 


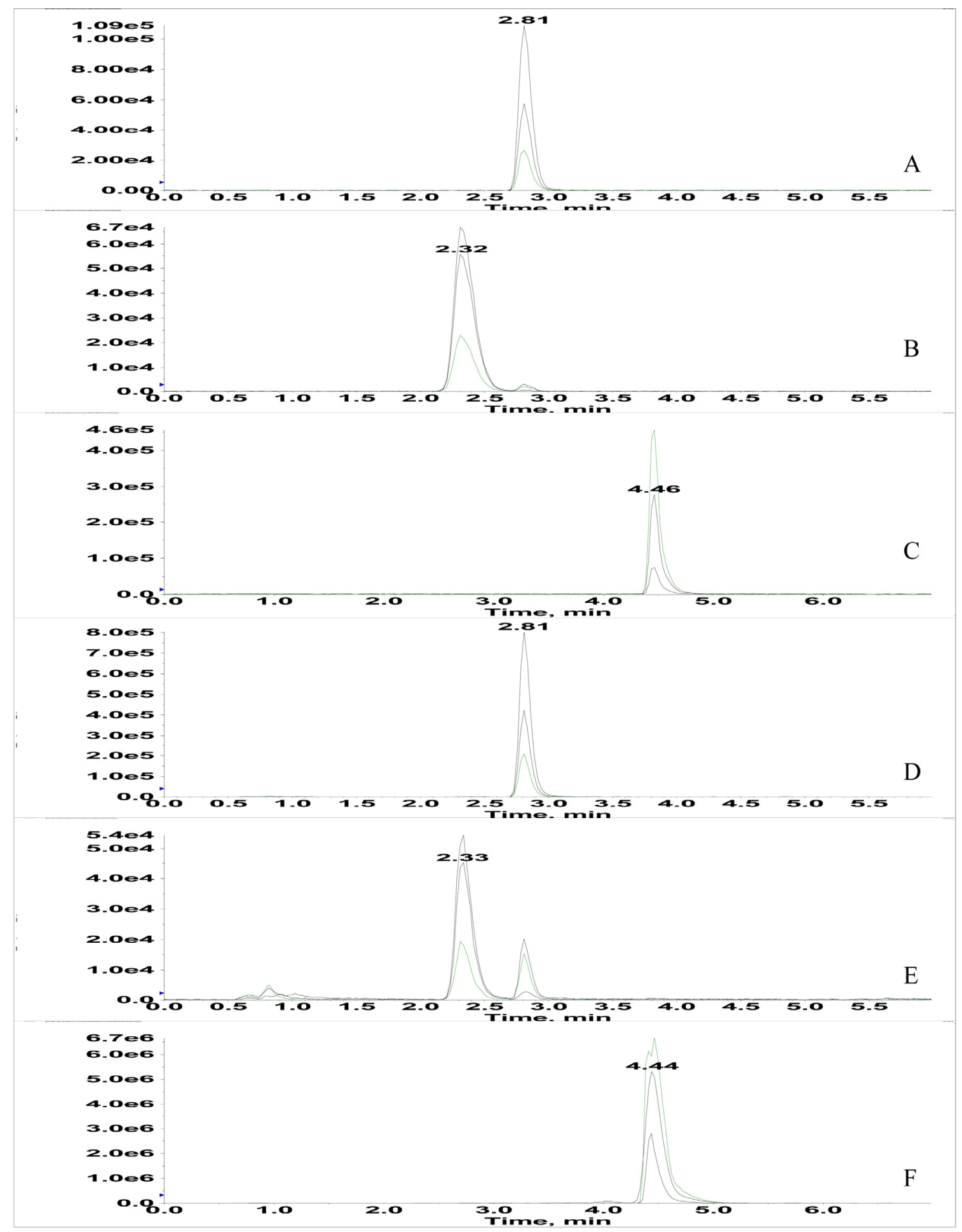

Figure 2. UPLC-MS/MS chromatography with MRM modes for (A) AFB1 standard; (B) AFB2 standard; (C) OTA standard; (D) AFB1 positive strain; (E) AFB2 positive strain; (F) OTA positive seed sample. Three precursor-to-product ion transitions were simultaneously monitored at $m / z$ 313.0-285.1, $\mathrm{m} / \mathrm{z} 313.0-241.3, \mathrm{~m} / \mathrm{z} 313.0-185.1$ for AFB1; $\mathrm{m} / \mathrm{z} 315.0-259.0$, $\mathrm{m} / \mathrm{z}$ 315.0-287.0, $\mathrm{m} / \mathrm{z}$ 315.0-243.0 for AFB2; 329.0-243.0, 329.0-311.0, 329.0-283.0 for AFG1; $m / z$ 331.0-235.1, $m / z$ 331.0-257.0, $m / z$ 331.0-189.0 for AFG2; and $m / z$ 404.0-358.1, $\mathrm{m} / \mathrm{z}$ 404.0-341.1, $\mathrm{m} / \mathrm{z} 404.0-239.2$ for OTA. 


\section{Experimental Section}

\subsection{Sample Collection}

Twelve kinds of medicinal seeds (Figure 3) were chosen on the basis of commercial availability and popularity, and were collected randomly from Anguo herbal market, Hebei province, China. The Anguo herbal marker is one of the four largest herbal markets in China. All samples were stored for 1 year before collection. For each kind of medicinal seed, about $500 \mathrm{~g}$ of sample were collected from each of 5 different herbal stores and put into sterile paper bags to obtain $2500 \mathrm{~g}$ of total weight. All samples were identified by Prof. Bengang Zhang, Institute of Medicinal Plant Development, Chinese Academy of Medical Sciences \& Peking Union Medical College, Beijing, China. The names, original plant, and producing regions of twelve medicinal seeds are presented in Table 3. Water activity of all medicinal seeds was measured in triplicate with a LabMaster-aw water activity measurement instrument (Novasina AG, Lachen, Switzerland) at $25^{\circ} \mathrm{C}$. Seeds that were large (including tangerine seeds, lychee seeds and lotus seeds) were cut into small pieces to facilitate internal measurements.

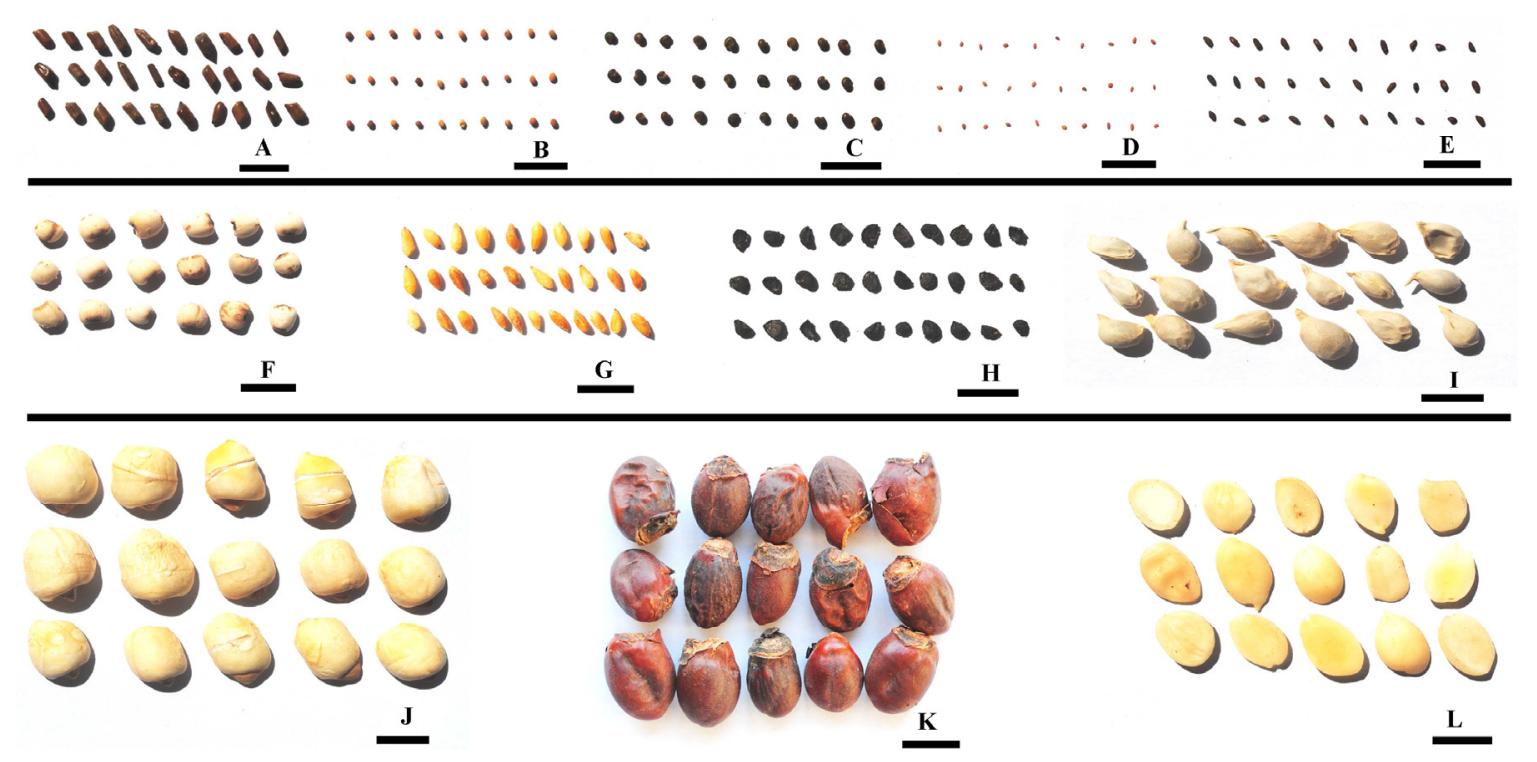

Figure 3. Seed samples. (A) Cassia seed; (B) Chinese dodder seed; (C) Flastem milkvetch seed; (D) Pepperweed seed; (E) Plantain seed; (F) Coix seed; (G) Platycladi seed; (H) Spiderflower seed; (I) Tangerine seed; (J) Lotus seed; (K) Lychee seed; (L) Peach seed. Bar $=10 \mathrm{~mm}$.

Table 3. Names, original plant and producing regions of studied medicinal seeds.

\begin{tabular}{cccc}
\hline No. & Name & Original Plant & Producing Regions \\
\hline 1 & Cassia seed & Cassia obtusifolia L. & Hebei province \\
2 & Chinese dodder seed & Cuscuta chinensis Lam. & Inner Mongolia autonomous region \\
3 & Coix seed & Coix lachryma-jobi L. var. ma-yuen (Roman.) Stpf & Guizhou province \\
& Flastem milkvetch & Astragalus complanatus R. Br. & Gansu province \\
4 & seed & Nelumbo nucifera Gaertn. & Shandong province \\
5 & Lotus seed & Litchi chinensis Sonn. & Guangxi autonomous region \\
\hline
\end{tabular}


Table 3. Cont.

\begin{tabular}{cccc}
\hline No. & Name & Original Plant & Producing Regions \\
\hline 7 & Peach seed & Prunus persica (L.) Batsch & Shandong province \\
8 & Pepperweed seed & Lepidium apetalum Willd. & Hebei province \\
9 & Plantain seed & Plantago asiatica L. & Liaoning province \\
10 & Platycladi seed & Platycladus orientalis (L.) Franco & Shandong province \\
11 & Spiderflower seed & Cleome gynandra L. & Hebei province \\
12 & Tangerine seed & Citrus reticulata Blanco & Guangdong province \\
\hline
\end{tabular}

\subsection{Isolation of Fungi}

Two different isolation methods were used to analyze the internal and superficial contaminating fungi. For internal fungal isolation, 100 of each medicinal seeds were surface sterilized using $75 \%$ ethanol for 1 min, followed by treatment with $\mathrm{NaClO}$ (3\% available chlorine) for $3 \mathrm{~min}$, and finally a second 75\% ethanol wash for $1 \mathrm{~min}$ [48]. The seeds were then dried on sterilized paper and 100 of each sample were aseptically plated in malt extract agar (MEA, $20 \mathrm{~g}$ of malt extract, $1 \mathrm{~g}$ of peptone, $20 \mathrm{~g}$ of dextrose, $15 \mathrm{~g}$ of agar, and brought up to $1 \mathrm{~L}$ with distilled water) dishes containing $50 \mathrm{ppm}$ tetracycline and $100 \mathrm{ppm}$ streptomycin. All plates were incubated at $25{ }^{\circ} \mathrm{C}$ and were examined for growth daily. For superficial fungal isolation, $10 \mathrm{~g}$ of each seed sample was added to $90 \mathrm{~mL}$ sterile water and mixed. This mixture was then shaken on a rotary shaker for approximately $30 \mathrm{~min}$ and subjected to a series of ten-fold serial dilution to a final dilution of $10^{-3}$. Aliquots consisting of $1 \mathrm{~mL}$ of each dilution were spread (in triplicate) on MEA containing $50 \mathrm{ppm}$ tetracycline and $100 \mathrm{ppm}$ streptomycin. One of the three sets of dilutions that averaged between 10 and 60 colonies per plate was selected for enumeration. The results of triplicate plating are expressed as the average $\mathrm{CFU} / \mathrm{g}$.

\subsection{Identification of Fungi}

Followed by preliminary morphological identification, every fungal colony was transferred and re-streaked onto MEA. With respect to Penicillium spp. and Aspergillus spp., colonies were streaked on Czapek Yeast Autolysate Agar (CYA, $1 \mathrm{~g}$ of $\mathrm{K}_{2} \mathrm{HPO}_{4}, 10 \mathrm{~mL}$ of Czapek concetrate, $5 \mathrm{~g}$ of yeast extract, $30 \mathrm{~g}$ of sucrose, $15 \mathrm{~g}$ of agar, and brought up to $1 \mathrm{~L}$ with distilled water) and Yeast Extract Sucrose Agar (YES, $20 \mathrm{~g}$ of yeast extract, $150 \mathrm{~g}$ of sucrose, $0.5 \mathrm{~g}$ of $\mathrm{MgSO}_{4} \cdot 7 \mathrm{H}_{2} \mathrm{O}, 20 \mathrm{~g}$ of agar, and brought up to $1 \mathrm{~L}$ with distilled water) and were incubated at $25{ }^{\circ} \mathrm{C}$ for 7 days. Colony colour was assessed according to The Methuen Handbook of Colour by Kornerup and Wanscher [49]. Other macroscopical and microscopic morphological observations (e.g. colony texture, conidiophore and conidia characteristics) were made according to previously published methods [50-53]. To verify the results of morphological characterization and identification of fungi, DNA of each strain was extracted using a commercial DNA extraction kit according to the instructions (Biomed Co., Ltd., Beijing, China). The $\beta$-tubulin gene was PCR amplified and sequenced [54]. With respect to fungal species other than Penicillium spp. and Aspergillus spp., the ITS gene was amplified and sequenced [55]. Obtained sequences were manually trimmed at the $\mathrm{N}$ and $\mathrm{C}$ terminals to delete low quality ends, and Basic Local Alignment Search Tool (BLAST) was used to identify the closest affiliated sequence in the GenBank/NCBI dataset. 


\subsection{Mycotoxin Production by Fungal Isolates}

Fungal strains were cultured and extracted according to Chen et al. [21] with several slight modifications. About $5 \mathrm{~g}$ dry fungal culture was blended with $100 \mathrm{~mL}$ methanol-water (80/20) and extracted using ultrasonography for $45 \mathrm{~min}$. The mixture was then filtered using quantitative filter paper. The filtrate was collected with an evaporating dish and was dried for $24 \mathrm{~h}$ at $60{ }^{\circ} \mathrm{C}$. The dried residue was then dissolved with $10 \mathrm{~mL}$ methanol/water (80/20) and was purified and concentrated by a solid phase extraction (SPE) column (NERCB-SPE, $100 \mathrm{mg} / 3 \mathrm{~mL}$, National Engineering Research Center for Biotechnology, Beijing, China). Each sample was filtrated through a $0.22 \mu \mathrm{m}$ PTFE filter before UPLC-MS/MS analysis. UPLC-MS/MS analysis was performed with a LC-20ADxR Prominence Liquid chromatograph (Shmadzu Corp., Kyoto, Japan) interfaced to a 5500 QTRAP MS system (AB Sciex Pte. Ltd., Framingham, MA, USA). The sample was separated using a ZORBAX Eclipse Plus C18 column $(2.1 \times 50$ mm, 1.8-Micron, Agilent Technologies Co., Ltd., Santa Clara, CA, USA). The mobile phase consisted of (A) acetonitrile containing $0.1 \%$ formic acid and (B) water containing $0.1 \%$ formic acid, The gradient procedure was as follows: $0.01-4.00 \mathrm{~min}, 70 \%-20 \% \mathrm{~B} ; 4.00-5.00 \mathrm{~min} 20 \%-70 \% \mathrm{~B}$; $5.00-6.00 \min 70 \% \mathrm{~B}$. The mass spectrometer was operated in the positive mode with Multiple Reaction Monitoring (MRM) at unit mass resolution. Three precursor-to-product ion transitions were simultaneously monitored at $m / z$ 313.0-285.1, $\mathrm{m} / \mathrm{z} 313.0-241.3, \mathrm{~m} / \mathrm{z} 313.0-185.1$ for AFB1; $\mathrm{m} / \mathrm{z}$ 315.0-259.0, $\mathrm{m} / \mathrm{z}$ 315.0-287.0, $\mathrm{m} / \mathrm{z}$ 315.0-243.0 for AFB2; 329.0-243.0, 329.0-311.0, 329.0-283.0 for AFG1; $\mathrm{m} / \mathrm{z} 331.0-235.1, \mathrm{~m} / \mathrm{z} 331.0-257.0, \mathrm{~m} / \mathrm{z} 331.0-189.0$ for AFG2; and $\mathrm{m} / \mathrm{z} 404.0-358.1, \mathrm{~m} / \mathrm{z} 404.0-341.1$, $\mathrm{m} / \mathrm{z}$ 404.0-239.2 for OTA. The MRM model was used for quantification of peaks. The limits of detection (LOD) and the limits of quantification (LOQ) were less than 0.05 and $0.1 \mu \mathrm{g} / \mathrm{kg}$, respectively.

\subsection{Analysis of Medicinal Seed Samples to Detect Natural Occurrence of AFs (AFB1, AFB2, AFG1, $A F G 2)$ and $O T A$}

Medicinal seeds were finely ground using a spice grinder until they were fine enough to pass through a sieve $(250 \mu \mathrm{m})$. About $5 \mathrm{~g}$ of this seed power was extracted and analyzed with the same methods described above.

\subsection{Statistical Analysis}

The software SPSS (SPSS version 15.0; SPSS Inc., Chicago, IL, USA, 2006) was used for data analysis. Comparisons of the mean values of data were performed using a Fisher's Least Significant Difference (LSD) test with a significance level at $\alpha=0.05$.

\section{Conclusions}

Despite the importance of medicinal seeds globally, little research has been done to characterize the mycobiota and occurrence of mycotoxigenic fungi in these seeds. The results presented here provide, for the first time, information about the presence and distribution of mycotoxins (aflatoxins and OTA) in commonly used medicinal seeds as well as mycotoxigenic fungi and their ability to produce these mycotoxins. For surface-sterilized medicinal seeds, C. globosporum, M. trigonosporus and A. alternata were most commonly detected. Patterns indicative of co-infection with C. globosporum and 
Penicillium spp., C. globosporum and Eurotium spp., Eurotium spp. and Aspergillus spp., A. niger and A. flavus were observed in tangerine, lychee, and platycladi seeds. Large titers of superficial fungi were observed and low similarity was found between superficial and internal mycobiota. UPLC-MS/MS analysis indicated that the occurrence of AFB1, AFB2, AFG1, AFG2, and OTA in commonly used medicinal seeds was rare, but when they were detected, they were detected at high levels. AFB1 was detected in platycladi seeds at $52.0 \mu \mathrm{g} / \mathrm{kg}$, and OTA was only detected in tangerine seeds at $92.3 \mu \mathrm{g} / \mathrm{kg}$. Subsequent analysis indicates that $A$. flavus and $P$. polonicum were the potential contributors to the high levels of AFB1 and OTA contamination in platycladi and tangerine seeds, respectively. Recently, the maximum permitted levels of AFs in several medicinal herbs have been set in China. Considering the toxicological effects of OTA, a maximum permitted level in several medicinal herbs is needed.

\section{Supplementary Materials}

Supplementary materials can be accessed at: http://www.mdpi.com/2072-6651/7/10/3858/s1.

\section{Acknowledgments}

The present study was supported by the National Natural Science Foundations of China No. 81274071 and No. 81473345, and the Program for Innovative Research Team in IMPLAD (PIRTI) No. IT1306.

\section{Author Contributions}

A.J.C., and W.G. conceived and designed the experiments; X.J., A.J.C., and Y.H. performed the experiments; X.J., A.J.C., and X.L. analyzed the data and prepared the manuscript. All authors discussed, edited and approved the final manuscript.

\section{Conflicts of Interest}

The authors declare no conflict of interest.

\section{References}

1. Akerele, O. Medicinal plants in traditional medicine. In Economic and Medicinal Plant Research; Wagner, H., Farnsworth, N., Eds.; Academic Press: London, UK, 1990; Volume 4, pp. 1-174.

2. MacLennan, A.H.; Wilson, D.H.; Taylor, A.W. Prevalence and cost of alternative medicine in Australia. Lancet 1996, 347, 569-573.

3. Barnes, P.M.; Powell-Griner, E.; McFann, K.; Nahin, R.L. Complementary and alternative medicine use among adults: United States, 2002. Semin. Integr. Med. 2004, 2, 54-71.

4. TCM exports set to rise at a healthy clip. Available online: http://www.chinese.cn/onlinelearning/ article/2012-03/22/content_420529.htm (accessed on 22 March 2012).

5. Chinese Pharmacopoeia Council. Chinese Pharmacopoeia; Chemical Industry Press: Beijing, China, 2010; Volume 1, pp. 1-361.

6. Hou, C.J.; Zhang, P.P.; Huo, D.Q. Advance in studies on the application of Semen Cassiae. Strait Pharm. J. 2007, 19, 7-9.

7. Sridhar, K.R.; Bhat, R. Lotus-A potential nutraceutical source. J. Agric. Technol. 2007, 3, 143-155. 
8. Binder, E.M.; Tan, L.M.; Chin, L.J.; HandI, J.; Richard, J. Worldwide occurrence of mycotoxins in commodities, feeds and feed ingredients. Anim. Feed Sci. Technol. 2007, 3-4, 265-282.

9. International Agency for Research on Cancer (IARC). Aflatoxins: B1, B2, G1, G2, M1. In Evaluation of Carcinogenic Risks of Chemicals to Humans; IARC Monographs: Lyon, France, 1993; Volume 56, pp. 245-395.

10. International Agency for Research on Cancer (IARC). Ochratoxin A. In Evaluation of Carcinogenic Risks of Chemicals to Humans; IARC Monographs: Lyon, France, 1993; Volume 56, pp. 489-521.

11. Bennett, J.W.; Klich, M. Mycotoxins. Clin. Microbiol. Rev. 2003, 16, 497-516.

12. Creppy, E.E. Human ochratoxicoses. J. Toxicol. Toxin Rev. 1999, 18, 273-293.

13. O'Brien, E.; Dietrich, D.R. Ochratoxin A: The continuing enigma. Crit. Rev. Toxicol. 2005, 35, 33-60.

14. Abarca, M.L.; Bragulat, M.R.; Castellá, G.; Cabañes, F.J. Ochratoxin A production by strains of Aspergillus niger var. niger. Appl. Environ. Microbiol. 1994, 60, 2650-2652.

15. Frisvad, J.C.; Frank, J.M.; Houbraken, J.A.M.P.; Kuijpers, A.F.A.; Samson, R.A. New ochratoxin A producing species of Aspergillus section Circumdati. Stud. Mycol. 2004, 50, 23-43.

16. Medina, A.; Mateo, R.; López-Ocaña, L.; Valle-Algarra, F.M.; Jiménez, M. Study of Spanish grape mycobiota and ochratoxin A production by isolates of Aspergillus tubingensis and other members of Aspergillus Section. Nigri. Appl. Environ. Microbiol. 2005, 71, 4696-4702.

17. Cabañas, R.; Bragulat, M.R.; Abarca, M.L.; Castellá, G.; Cabañes, F.J. Occurrence of Penicillium verrucosum in retail wheat flours from the Spanish market. Food Microbiol. 2008, 25, 642-647.

18. Joint FAO/WHO Expert Committee on Food Additives (JECFA). Safety Evaluation of Certain Mycotoxins in Food: WHO Food Additives Series, No. 59, 2008. Available online: http:/whqlibdoc. who.int/publications/2008/9789241660594_eng.pdf (accessed on 18 November 2009).

19. Logrieco, A.; Bottalico, A.; Mulé, G.; Moretti, A.; Perrone, G. Epidemiology of toxigenic fungi and their associated mycotoxins for some Mediterranean crops. Eur. J. Plant Pathol. 2003, 109, 645-667.

20. Chen, A.J.; Huang, L.F.; Wang L.Z.; Tang, D.; Cai, F.; Gao, W.W. Occurrence of toxigenic fungi in ochratoxin A contaminated licorice root. Food Addit. Contam. A 2011, 28, 1091-1097.

21. Chen, A.J.; Tang, D.; Zhou, Y.Q.; Sun, B.D.; Li, X.J.; Wang, L.Z.; Gao, W.W. Identification of ochratoxin a producing fungi associated with fresh and dry liquorice. PLOS ONE 2013, 8, e 78285.

22. Commission of the European Communities. Commission regulation (EC) No 105/2010 of 5 February 2010 setting maximum levels for certain contaminants in foodstuffs as regards ochratoxin A. Off. J. Eur. Union 2010, 35, 7-8.

23. Commission of the European Communities. Commission Regulation (EC) No 1881/2006 of 19 December 2006 setting maximum levels for certain contaminants in foodstuffs. Off. J. Eur. Union 2006, 364, 5-24.

24. Hao, A.Y.; Zhao, L.Y.; Liu, Y.H.; Wang, G.; Jin, H.Y.; Bi, X.L.; Men, Q.M. HPLC determination of aflatoxin residues in traditional Chinese medicine Yinpian with post column photochemical derivation and fluorescence detection. Chin. J. Pharm. Anal. 2012, 32, 2203-2207.

25. Kong, W.J.; Wei, R.W.; Logrieco, A.F.; Wei, J.H.; Wen, J.; Xiao, X.H.; Yang, M.H. Occurrence of toxigenic fungi and determination of mycotoxins by HPLC-FLD in functional foods and spices in China markets. Food Chem. 2014, 146, 320-326. 
26. Yang, M.H.; Chen, J.M.; Zhang, X.H. Immunoaffinity column clean-up and liquid chromatography with post-column derivatization for analysis of aflatoxins in traditional Chinese medicine. Chromatographia 2005, 62, 499-504.

27. Covarelli, L.; Beccari, G.; Salvi, S. Infection by mycotoxigenic fungal species and mycotoxin contamination of maize grain in Umbria, central Italy. Food Chem. Toxicol. 2011, 49, 2365-2369.

28. Goncalez, E.; Nogueira, J.H.C.; Fonseca, H.; Felicio, J.D.; Pino, F.A.; Corrêa, B. Mycobiota and mycotoxins in Brazilian peanut kernels from sowing to harvest. Int. J. Food Microbiol. 2008, 123, 184-190.

29. Kaaya, A.N.; Kyamuhangire, W. The effect of storage time and agroecological zone on mould incidence and aflatoxin contamination of maize from traders in Uganda. Int. J. Food Microbiol. 2006, 110, 217-223.

30. Ok, H.E.; Kim, D.M.; Kim, D.; Chung, S.H.; Chung, M.; Park, K.H.; Chun, H.S. Mycobiota and natural occurrence of aflatoxin, deoxynivalenol, nivalenol and zearalenone in rice freshly harvested in South Korea. Food Control 2014, 37, 284-291.

31. Sánchez-Hervás, M.; Gil, J.V.; Bisbal, F.; Ramón, D.; Martínez-Culebras, P.V. Mycobiota and mycotoxin producing fungi from cocoa beans. Int. J. Food Microbiol. 2008, 125, 336-340.

32. Sacchi, C.; González, H.H.L.; Broggi, L.E.; Pacind, A.; Resnik, S.L.; Cano, G.; Taglieri, D. Fungal contamination and mycotoxin natural occurrence in oats for race horses feeding in Argentina. Anim. Feed Sci. Technol. 2009, 152, 330-335.

33. Adebajo, L.O.; Popoola, O.J. Mycoflora and mycotoxins in kolanuts during storage. Afr. J. Biotechnol. 2003, 2, 365-368.

34. Atehnkeng, J.; Ojiambo, P.S.; Donner, M.; Ikotun, T.; Sikora, R.A.; Cotty, P.J.; Bandyopadhyay, R. Distribution and toxigenicity of Aspergillus species isolated from maize kernels from three agro-ecological zones in Nigeria. Int. J. Food Microbiol. 2008, 122, 74-84.

35. Nakai, V.K.; Rocha, L.O.; Goncalez, E.; Fonseca, H.; Ortega, E.M.M.; Corrêa, B. Distribution of fungi and aflatoxins in a stored peanut variety. Food Chem. 2008, 106, 285-290.

36. Rodrigues, P.; Venâncio, A.; Lima, N. Mycobiota and mycotoxins of almonds and chestnuts with special reference to aflatoxins. Food Res. Int. 2012, 48, 76-90.

37. Li, R.H.; Feng, L.; Ma, X.Y.; Sun, Y.J.; Liu, S.P.; Jia, T.Z. Relationship between contents of fatty oil, total diterpenoids and quality of Platycladi Semen. Chin. J. Exp. Tradit. Med. Form. 2015, 21, 9-11.

38. Mellon, J.E.; Cotty, P.J.; Dowd, M.K. Influence of lipids with and without other cottonseed reserve materials on aflatoxin B1 production by Aspergillus flavus. J. Agric. Food Chem. 2000, 48, 3611-3615.

39. Bayman, P.; Baker, J.L.; Mahoney, N.E. Aspergillus on tree nuts: Incidence and associations. Mycopathologia 2002, 155, 161-169.

40. Esteban, A.; Abarca, M.L.; Bragulat, M.R.; Cabañes, F.J. Effect of water activity on ochratoxin A production by Aspergillus niger aggregate species. Int. J. Food Microbiol. 2006, 108, 188-195.

41. Klich, M.A. Environmental and developmental factors influencing aflatoxin production by Aspergillus flavus and Aspergillus parasiticus. Mycoscience 2007, 48, 71-80.

42. Umikalsom, M.S.; Ariff, A.B.; Zulkifli, H.S.; Tong, C.C.; Hassan, M.A.; Karim, M.I.A. The treatment of oil palm empty fruit bunch fiber for subsequent use as substrate for cellulase production by Chaetomium globosum Kunze. Bioresource Technol. 1997, 62, 1-9. 
43. El-Said, A.H.M.; El-Hady, G. Effect of moisture contents on the biodiversity of fungi contaminating Cuminum cyminum and Pimpinella anisum seeds under storage periods and amylolytic activity of fungal isolates. Int. J. Food Microbiol. 2014, 3, 969-991.

44. Hassegawa, R.H.; Fonseca, H.; Fancelli, A.L.; da Silva, V.N.; Schammass, E.A.; Reis, T.A.; Corrêa, B. Influence of macro and micronutrient fertilization on fungal contamination and fumonisin production in corn grains. Food Control 2008, 19, 36-43.

45. Marin, S.; Sanchis, V.; Arnau, F.; Ramos, A.J.; Magan, N. Colonisation and competitiveness of Aspergillus and Penicillium species on maize grain in the presence of Fusarium moniliforme and Fusarium proliferatum. Int. J. Food Microbiol. 1998, 45, 107-117.

46. Barros, G.; Torres, A.; Chulze, S. Aspergillus flavus population isolated from soil of Argentina's peanut-growing region. Sclerotia production and toxigenic proflle. J. Sci. Food Agric. 2005, 85, 2349-2353.

47. Vaamonde, G.; Patriarca, A.; Pinto, V.F.; Comeria, R.; Degrossi, C. Variability of aflatoxin and cyclopiazonic acid production by Aspergillus section Flavi from different substrates in Argentina. Int. J. Food Microbiol. 2003, 88, 79-84.

48. Huang, W.Y.; Cai, Y.Z.; Xing, J.; Corke, H.; Sun, M. A potential antioxidant resource: Endophytic fungi from medicinal plants. Econ. Bot. 2007, 61, 14-30.

49. Kornerup, A.; Wanscher, J.H. Methuen Handbook of Colour, 3rd ed.; Methuen Eyrn: London, UK, 1978; pp. 1-252.

50. Carmichael, J.W.; Kendrick, W.B.; Conners, I.L.; Sigler, L. Genera of Hyphomycetes; The University of Alberta Press: Edmonton, AB, Canada, 1980; pp. 1-386.

51. Klich, M.A. Identification of Common Aspergillus Species; Centraalbureau voor Schimmelculturs: Utrecht, The Netherlands, 2002; pp. 1-116.

52. Pitt, J.I. The Genus Penicillium and Its Teleomorphic States Eupenicillium and Talaromyces, 1st ed.; Academic Press: Lodon, UK, 1979; pp. 1-634

53. Samson, R.A.; Frisvad, J.C. Penicillium subgenus Penicillium: New taxonomic schemes, mycotoxins and other extrolites. Stud. Mycol. 2004, 49, 1-253.

54. Glass, N.L.; Donaldson, G.C. Development of primer sets designed for use with the PCR to amplify conserved genes from filamentous Ascomycetes. Appl. Environ. Microbiol. 1995, 61, 1323-1330.

55. White, T.J.; Bruns, T.; Lee, S.; Taylor, J. Amplification and direct sequencing of fungal ribosomal RNA genes for phylogenetics. In PCR Protocols: A Guide to Methods and Applications. Innis, M.A., Gelfand, D., Sninsky, J., White, T., Eds.; Academic Press: New York, NY, USA, 1990; pp. 315-312.

(C) 2015 by the authors; licensee MDPI, Basel, Switzerland. This article is an open access article distributed under the terms and conditions of the Creative Commons Attribution license (http://creativecommons.org/licenses/by/4.0/). 